
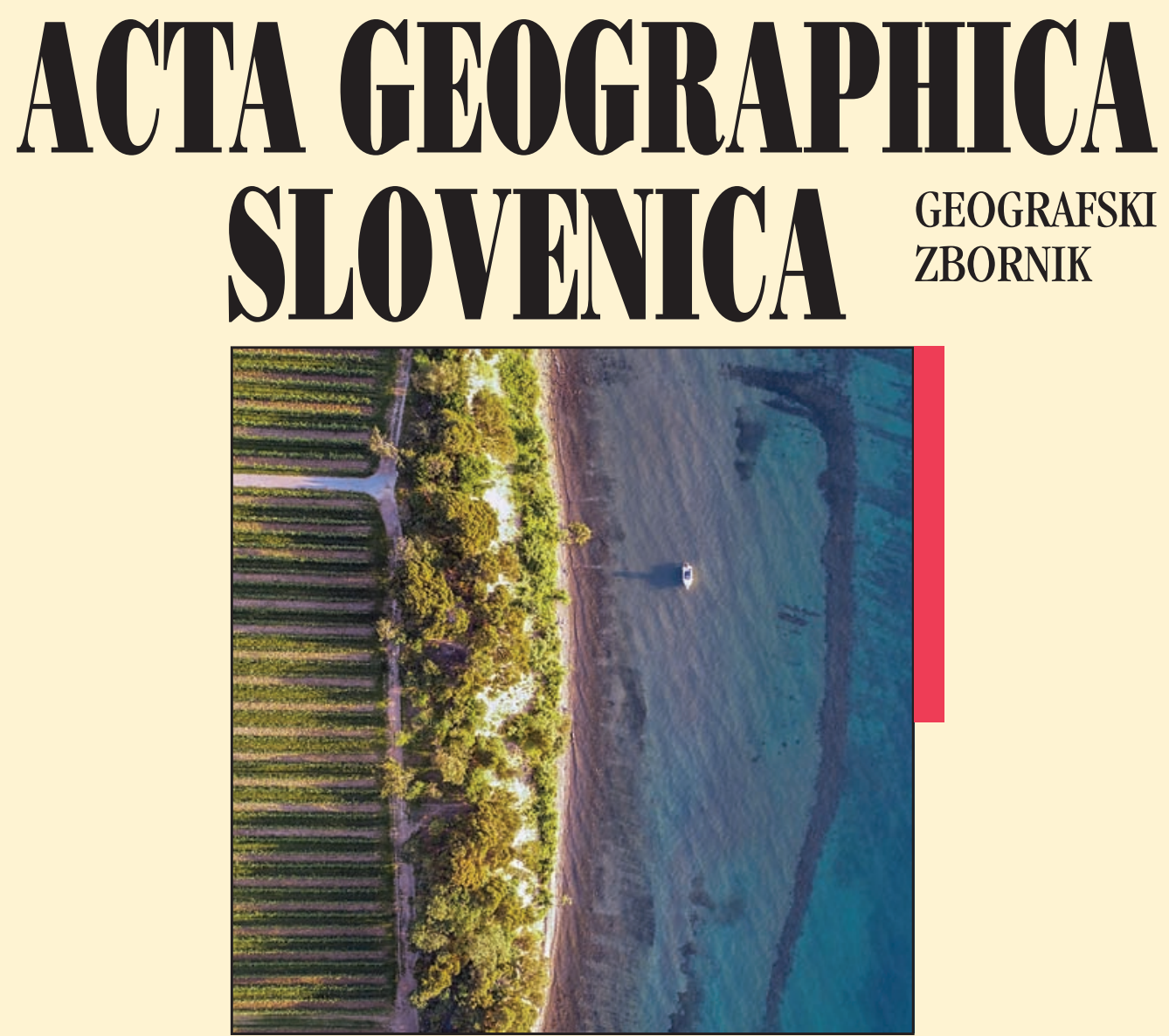


\section{ACTA GEOGRAPHICA SLOVENICA GEOGRAFSKI ZBORNIK 60-1 - 2020}

\section{Contents}

Mojca POKLAR

Comparison of the sonar recording method and the aerial photography method

for mapping seagrass meadows

Vanja PAVLUKOVIĆ, Uglješa STANKOV, Daniela ARSENOVIĆ

Social impacts of music festivals: A comparative study of Sziget (Hungary) and Exit (Serbia)

Péter János KISS, Csaba TÖLGYESI, Imola BÓNI, László ERDÖS, András VOJTKÓ, István Elek MAÁK, Zoltán BÁTORI

The effects of intensive logging on the capacity of karst dolines to provide potential microrefugia for cool-adapted plants

Radu SĂGEATĂ

Commercial services and urban space reconversion in Romania (1990-2017)

Kristina IVANČIČ, Jernej JEŽ, Blaž MILANIČ, Špela KUMELJ, Andrej ŠMUC Application of a mass movement susceptibility model in the heterogeneous Miocene clastic successions of the Slovenj Gradec Basin, northeast Slovenia

Andrej GOSAR

Measurements of tectonic micro-displacements within the Idrija fault zone in the Učja valley (W Slovenia)

Piotr RAŹNIAK, Sławomir DOROCKI, Anna WINIARCZYK-RAŹNIAK

Economic resilience of the command and control function of cities in Central and Eastern Europe

Mateja FERK, Rok CIGLIČ, Blaž KOMAC, Dénes LÓCZY

Management of small retention ponds and their impact on flood hazard prevention in the Slovenske Gorice Hills

\section{Gregor KOVAČIČ}

Sediment production in flysch badlands: A case study from Slovenian Istria

Vesna LUKIĆ, Aleksandar TOMAŠEVIĆ

Immigrant integration regimes in Europe: Incorporating the Western Balkan countries

Mitja DURNIK

Community development: Local Immigration Partnerships in Canada and implications for Slovenia

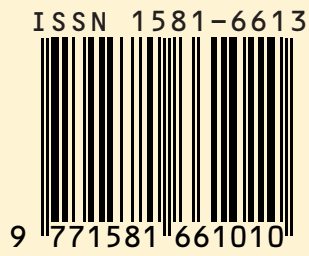




\section{MANAGEMENT OF SMALL RETENTION PONDS AND THEIR IMPACT ON FLOOD HAZARD PREVENTION IN THE SLOVENSKE GORICE HILLS}

Mateja Ferk, Rok Cigličc, Blaž Komac, Dénes Lóczy

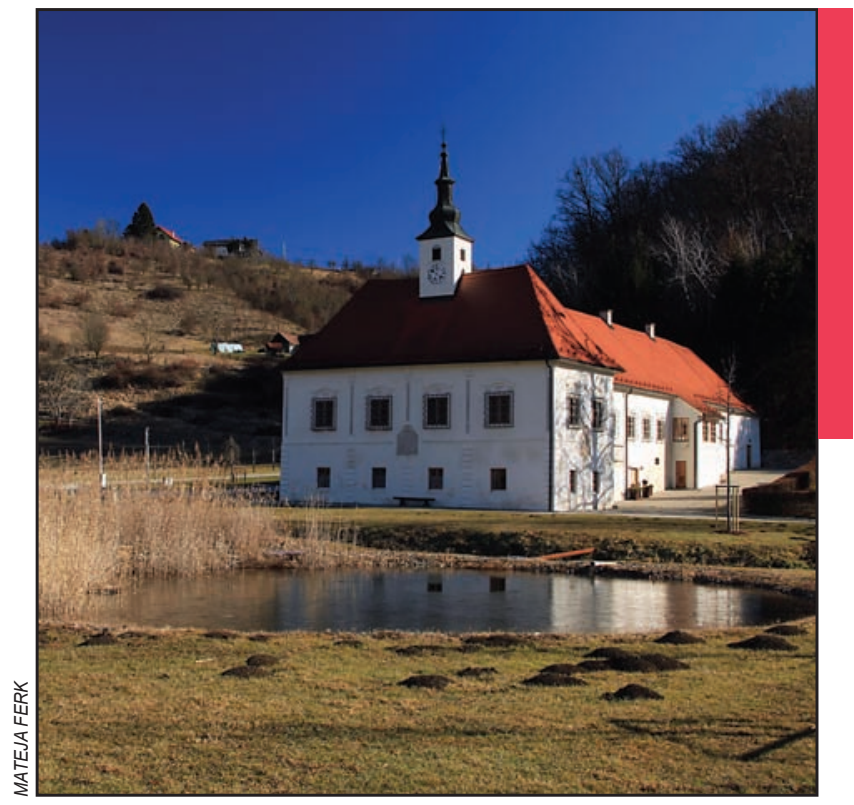

Retention pond at the former Benedictine monastery at Jareninski Dvor. 
DOI: https://doi.org/10.3986/AGS.7675

UDC: 911:556.18(497.41)

627.13:556.166(497.41)

COBISS: 1.01

Mateja Ferk ${ }^{1}$, Rok Cigličํㅜ, Blaž Komac' ${ }^{1}$ Dénes Lóczy²

\title{
Management of small retention ponds and their impact on flood hazard prevention in the Slovenske Gorice Hills
}

\begin{abstract}
One of the methods of water resource management is to construct small retention ponds. Within the framework of the »Possible ecological control of flood hazard in the hilly regions of Hungary and Slovenia» project the management of small ponds and their impact on flood prevention were studied in selected catchments. Data on pond management were gathered from interviews with pond owners. In a pilot study, we conducted an inventarisation and classification of all retention ponds. Primarily they were constructed for more specific use: fishing, irrigation, watering livestock. These functions have been gradually replaced by leisure-time activities, aesthetics, and tourism. Spring, stream and rainfall-fed ponds prevail in the pilot area and reduce the flood risk. Due to the increased variability of precipitation patterns ponds are also becoming an important measure to limit drought consequences at a local level.
\end{abstract}

KEY WORDS: hydrogeography, natural hazards, floods, water management, dams, detention ponds, Slovenia

\section{Upravljanje malih vodnih zadrževalnikov in njihov vpliv na poplavno varnost Slovenskih goric}

POVZETEK: Eden od načinov gospodarjenja z vodnimi viri je izgradnja majhnih zadrževalnih ribnikov. V okviru projekta »Primerni ekološki ukrepi na področju poplavne nevarnosti v hribovitem območju Madžarske in Slovenije smo preučili upravljanje majhnih ribnikov in njihov vpliv na preprečevanje poplav v izbranih porečjih. Podatke o upravljanju ribnika smo zbrali s pomočjo intervjujev z lastniki ribnikov. V pilotni študiji smo izvedli inventarizacijo in razvrščanje zadrževalnih ribnikov. V glavnem so bili zgrajeni za namensko uporabo, kot je ribolov, namakanje, napajanje živine. Te funkcije so postopoma nadomestile prosti čas, estetika in turizem. Na pilotnem območju prevladujejo zadrževalniki, ki jih polnijo izviri, vodotoki in padavine, in zmanjšujejo poplavno ogroženost. Zaradi večje variabilnosti padavin postajajo ribniki na lokalni ravni tudi pomemben ukrep za omejevanje posledic suše.

KLJUČNE BESEDE: hidrogeografija, naravne nesreče, poplave, upravljanje voda, pregrade, vodna zajetja, Slovenija

The paper was submitted for publication on November $12^{\text {th }}, 2019$.

Uredništvo je prejelo prispevek 12. novembra 2019.

\footnotetext{
${ }^{1}$ Research Centre of the Slovenian Academy of Sciences and Arts, Anton Melik Geographical Institute, Ljubljana, Slovenia mateja.ferk@zrc-sazu.si,rok.ciglic@zrc-sazu.si,blaz.komac@zrc-sazu.si

${ }^{2}$ University of Pécs, Institute of Geography and Earth Sciences, Pécs, Hungary

loczyd@gamma.ttk.pte.hu
} 


\section{Introduction}

In the past, water management focused on building and managing water supply infrastructure. This approach brought into use large-scale centralized water storage infrastructure systems for irrigation, sewage, and energy production which were also used for flood control. According to the data of the World Commission on Dams (World register ... 2020) there were more than 50,000 dams globally in 2019. In Slovenia, there are 47 large dams (Komac and Zorn 2016). This so-called hard path water management has improved human water security worldwide. However, the diminishing capacity of the hard path to solve emerging water problems led water managers to seek new approaches. Soft path solutions focus on institutional reforms, small-scale interventions, the introduction of water-efficient technologies, and the management of agricultural, industrial, and residential water use. They can better address future water scarcity where hard path approaches have not been successful (Wutich et al. 2014). Retention ponds on fluvial systems are a useful soft path approach and contribute to water resource management by influencing water discharge and sediment transport dynamics (Verstraeten and Poesen 2001; Koskiaho 2003), and water chemistry (Fairchild and Velinsky 2009).

Retention ponds can be divided by their size into two categories. Large ponds or reservoirs are flood retention dams, flood control dams, water retention objects, and sediment traps, while small retention ponds are fishing ponds, watering holes, and pools. The dams of large retention ponds are mostly of concrete or combined construction, while small retention ponds involve simpler earthworks (Steinman and Banovec 2008; Table 1). In Slovenia, large ponds were mostly built for energy production, drinking and technological water storage, flood and drought management, and irrigation for food production (Širca 2010). Small retention ponds, on the other hand, provide water for irrigation and support secondary uses, such as fishing and tourism. With large retention ponds, the detention time is from one to several years, while it lasts from one to several days in the small ones.

In Slovenia, water infrastructure management is beyond individual interests and is a public utility service concessed by the Slovenian Environment Agency. However, the List of the existing water infrastructure excludes sediment retention objects, their inflow and outflow channels, and irrigation and drainage systems, while only the barriers and dams are included (Seznam obstoječe ... 2006). The Waters Act (Zakon o vodah 2002) lists 40 dams as water infrastructure (Globevnik 2012) while the Rules to determine water infrastructure (Pravilnik o določitvi ... 2005) declare the formal status of water infrastructure, especially related to maintenance. Water infrastructure is part of geodetic data and governed in the EU by the INSPIRE Directive (Infrastructure for ... 2017).

In Slovenia, the water infrastructure is governed by the National water management program, water management plans, remediation programs, and other water management programs. The National water management program determines water management policy, as well as the goals, directives, and priorities

Table 1: Types of water ponds according to the construction and type of distribution of water pressure (Steinman and Banovec 2008).

\begin{tabular}{|c|c|c|}
\hline First level division (building material) & Second level division & Third level division \\
\hline \multirow[t]{7}{*}{ concrete } & \multirow[t]{2}{*}{ gravity } & full \\
\hline & & relieved \\
\hline & \multirow[t]{2}{*}{ pillar } & with reinforced part \\
\hline & & with arches \\
\hline & \multirow[t]{3}{*}{ arch } & cylindrical \\
\hline & & equilateral \\
\hline & & domed \\
\hline \multirow[t]{5}{*}{ earth } & \multirow[t]{2}{*}{ earth fill } & homogeneous \\
\hline & & layered \\
\hline & \multirow[t]{3}{*}{ rock fill } & folded \\
\hline & & metalled \\
\hline & & layered \\
\hline combined & 1 & I \\
\hline
\end{tabular}


for water use, protection, and management. At the catchment level, the period 2016-2021 is regulated by the Adriatic Sea Watershed Management Plan (Načrt upravljanja voda na vodnem območju Jadranskega ... 2016; Uredba o načrtih upravljanja 2016) and the Danube River Catchment Management Plan (Načrt upravljanja voda na vodnem območju Donave ... 2016; Uredba o načrtih upravljanja 2016).

Water infrastructure objects are documented in the Water Register, the official record of the Slovenian Water Agency (E-vode 2019). It encompasses 55 databases on water, including hydrology, water typology, water areas, nature protection areas and flood hazard maps (Pravilnik o vodnem ... 2017). Although new data regarding hydrology and use of the water areas are available they lack coherence as they were created through desktop work, without any field research (Barborič et al. 2017). Significant differences were indicated between the official documentation on water infrastructure and the actual state in nature (Sodnik, Kogovšek and Mikoš 2014). This especially applies to small water infrastructure objects, such as ponds.

Two regulations on retention ponds exist in Slovenia, but they originally support the management of large retention ponds and they are only applied to hydroelectricity dams. These are the Rules on the technical monitoring of high water dams (Pravilnik o tehničnem ... 1966) and the Rules on the monitoring of seismicity in the area of large dams (Pravilnik o opazovanju ... 1999). The Instructions for preparing risk assessments for dam barrier failures (Lenart, Rajar and Širca 2017) were never passed in the Republic of Slovenia, so today's practice is based on an almost half-a-century-old Yugoslav regulation (Uputstvo ... 1975). At the European level, the core document regulating retention ponds is the Manifesto on Dams and Reservoirs (Manifesto ... 2015), while the Kyoto Protocol (World declaration ... 2012) governs the issue at global level.

In general, the situation is rather bad as regards the comprehensive approach to planning, construction, operation and safety rules for water dams in Slovenia. The rules are scattered across construction and other legislation, we lack orderliness and even a comprehensive overview of the situation (Širca, Ravnikar Turk and Zadnik 2010). Large retention ponds (hydroelectricity dams are excluded) are poorly maintained and not regularly examined. Past constant changes and scattered organization of retention pond management caused bad management practices. Archival data were often lost and sometimes even the construction data are missing (Širca, Ravnikar Turk and Zadnik 2010). Many so-called sediment trap objects are not regularly cleaned and no longer retain sediments (Papež 2010), leading to erosion (Kračun 2010) and increasing flash flood hazard (Komac and Zorn 2011). Since their construction, the barriers have not been adjusted to the current hydrological, climate, and land use conditions (Zemeljske ... 2016), exposing the regions to combined and cascade disasters (Komac 2015).

Therefore, the hazard in the Slovenske Gorice Hills should not be ignored although the region has lower dams than other regions in Slovenia. Their less cohesive building material and structure need to be considered. As even large retention facilities face several worrying issues, it is even more challenging to enforce legislation for small retention ponds (Širca 2010). Furthermore, incomplete records on small retention ponds and bodies of water are an important, even pressing issue, urgently calling for their comprehensive analysis and management. The management of large dams faces numerous issues and has been put to the agendas of different national and international organizations. Small retention pond management, on the other hand, encounters several challenges that have not been properly addressed yet. An important issue is the rapid filling of the ponds with sediment which increases maintenance costs (Verstraeten and Poesen 1999; 2000). Also, the improved accessibility of water in the last century for people and their livestock decreased the need for ponds in rural areas, consequently they are increasingly abandoned (Mioduszewski 2012).

The project entitled Possible ecological control of flood hazard in the hilly regions of Hungary and Slovenia is one of the attempts to address this question in the Pannonian Basin. It studies the suitability of ecological measures for decreasing floods hazard in the hilly regions of Eastern Slovenia. Namely, while sustainable reduction of flood risk can be achieved by large scale spatial planning and land use adaptation in the downstream river valleys, water retention areas in small basins can effectively lower the frequency of floods (Hooijer et al. 2004; Richert et al. 2011; Kijowska-Strugała and Bucała-Hrabia 2019). It has been established that small retention ponds are especially effective in peak flow reduction on a local scale (Chrétien et al. 2016). Furthermore, studies have shown they have a beneficial impact on limiting erosion (Verstraeten and Poesen 1999; Koskiaho 2003), as well as improving runoff quality (Chrétien et al. 2016) and are an added ecological value of the environment (Mioduszewski 2012).

In the research, we focused on ponds that are defined as small artificial structures to retain freshwater. We investigated the management of such ponds in the Pesnica River catchment (part of Slovenske Gorice 
Hills). The detailed analysis of the retention ponds in two representative lower-ranked catchments - Jarenina and Vukovje creeks consisted of spatial analysis and in-depth interviews. The aim of the paper is to present a comprehensive assessment of management practices of small ponds, and their impact on flood prevention in the Slovenske Gorice Hills.

\section{Hydrological features of the Slovenske Gorice Hills}

The Slovenske Gorice Hills are a hilly region in north-east Slovenia (Perko 1998). The area is located in the west of the Pannonian Basin between the Drava River to the south and the Mura River to the north. The hills are composed of Neogene marine sediments: mostly clays, sandy marl, sandstone, and conglomerates, with local outcrops of limestone (Belec 1998; Kert 1998). According to the calculations using a version of the Gavrilović equation according to Pintar, Mikoš and Verbovšek (1986), the annual sediment production in Slovenske Gorice Hills is $1031.6 \mathrm{~m}^{3} / \mathrm{km}^{2}$ or $16.5 \mathrm{t} / \mathrm{ha}$ and the annual sediment yield is $639.7 \mathrm{~m}^{3} / \mathrm{km}^{2}$ or $10.2 \mathrm{t} / \mathrm{ha}$ (Hrvatin et al. 2019). Water flows quickly from the impermeable bedrock to the lowlands and the Slovenske Gorice Hills have a dense stream network $\left(2.1 \mathrm{~km} / \mathrm{km}^{2}\right)$. Relatively high precipitation and high temperatures contribute to high evapotranspiration during summer when many small watercourses dry up. Specific runoff and discharge coefficients are below average in the area (Kolbezen 1998; Frantar 2008a; 2008b). In recent years, a smaller share of snow precipitation has increased water runoff during winter (Žiberna 2017). The share of forest below the Slovenian average covering about a third of the area (Kert 1998) decreases water retention in source areas. However, in the last hundred years, the landscape has changed considerably: the share of forests has increased, replacing orchards and vineyards on steep slopes (Ciglič and Nagy 2019; Deriaz et al. 2019). In addition, modernization of agriculture led to terrace abandonment in viticulture (Pipan and Kokalj 2017). Small amount of precipitation, high evapotranspiration, quick runoff, and poor retention capacity increase the frequency of droughts (Frantar 2008a; 2008b; Kozjek, Dolinar and Skok 2017; Žiberna 2017).

The valley floors had often been flooded before the regulation of watercourses in the second half of the $20^{\text {th }}$ century. These measures have decreased flood hazard in the valleys but as the streams have been changed by man, water runs off faster. Water discharge varies significantly; it rises during downpours and snowmelts and lowers during droughts when the streams even desiccate (Kert 1998). Torrential floods are common and occur during local downpours in summer and autumn (Trobec 2016). As noted elsewhere (Frantar and Hrvatin 2005; Kovačič 2016; Hrvatin and Zorn 2017), the precipitation trend in the period 1961-2016 is positive in the autumn and winter months (Žiberna 2017). The increase of precipitation during the colder months with limited evapotranspiration poses a threat to flood security and increases the importance of maintaining small retention ponds for the future.

Due to significant variability of precipitation and water discharge, the area of the Slovenske Gorice Hills is subject to high uncertainty of water supply management: on one hand, it receives short-lived, heavy downpours and torrential floods with a quick water discharge, while on the other hand, long periods with very scarce and low amounts of precipitation occur leading to water shortages. This is why innovative management practices are needed in order to increase water retention during droughts and prevent high water runoff. One of the measures for water retention in the periods of drought and for preventing runoff during the period of more abundant precipitation is ensuring proper land use (for example, by afforestation) and water infrastructure management. The latter involves riverbanks maintenance and excavating or building small and large water retention ponds.

\subsection{The Pesnica River Valley}

The Pesnica River Valley is located in the central part of the Slovenske Gorice Hills. It runs from the northwest to the southeast collecting most of the waters in the area. The catchment is of asymmetrical shape with the left, north-eastern bank more hydrologically developed. The valley floor is a few $100 \mathrm{~m}$ wide above Zgornja Kungota, and its width extends to about $3 \mathrm{~km}$ in the lower reaches near Ptuj. The valley was developed in Miocene clastic sediments, mainly sandstone and marl. The flat valley bottom is filled with fluvial deposits and was shaped by the river's frequent floods in a wetland environment. In the past, a very low 
stream gradient $-1.7 \%$ (Kobold 2012) caused the meandering of the river. This can be clearly observed on the Josephine Military Map (e.g. Zorn 2007) or on the map of the Franciscean Cadastre (Natek 1992; Gabrovec, Bičík and Komac 2019; Kladnik et al. 2019). The meandering river channel was channelized in the $1960 \mathrm{~s}$ in order to support agriculture. Of its approximately $69 \mathrm{~km}$ course $(65 \mathrm{~km}$ on the Slovenian territory), about $50 \mathrm{~km}$ were regulated. In order to prevent flash floods about $90 \mathrm{~km}$ of the tributaries were also regulated (Juvan et al. 1997). In total, 13\% of the stream network surface has been meliorated (Leitinger 2012) and only the headwaters of some small tributaries and small narrow valleys remained undisturbed. With channelization the wetland was converted to farmland, on the other hand, channelization increases flood hazard (Lóczy, Kis and Schweitzer 2009; Lóczy and Dezső 2013). The flood hazard prevention measures in the Pesnica River Valley included the building of several large retention ponds. The largest retention pond along the Pesnica River is the Pernica accumulation lake (Figure 1). It consists of two parts; the Pernica 1 and Pernica 2 retention ponds, divided by a dam and a floodgate. The Jarenina and Vukovje creeks flow into the Pernica 1 retention pond. The Pesnica River contributes water into the Pernica 2 retention pond. Also the Pristava retention pond lies on the Pesnica River, while all other retention ponds are located on its tributaries (Figure 2).

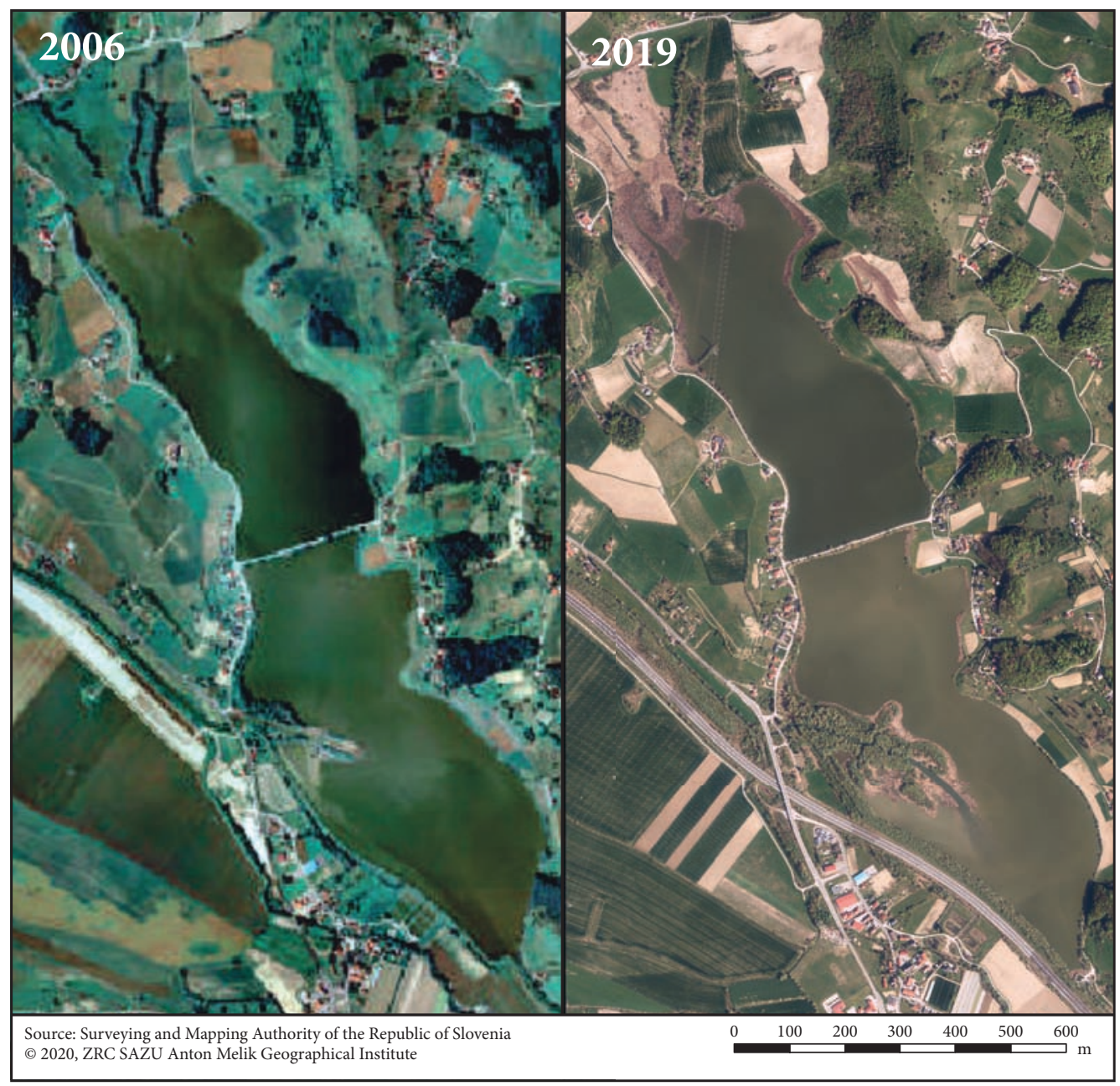

Figure 1: Pernica accumulation lake in 2006 and 2016. 


\subsection{Spatial analysis of the Jarenina Creek and Vukovje Creek catchments}

The catchments of Jarenina and Vukovje Creeks are similar by their average elevation $(306 \mathrm{~m}$ and $318 \mathrm{~m}$, respectively) which is about $50 \mathrm{~m}$ higher than the average elevation of the Slovenske Gorice Hills. The valley floors lie at an altitude of $250 \mathrm{~m}$, while the highest peaks of the hills exceed $400 \mathrm{~m}$ in the north-western part of the Jarenina Creek catchment. Slope gradients, which were calculated with a $5 \mathrm{~m}$ resolution, range between $13^{\circ}$ and $14^{\circ}$, with a maximum of about $50^{\circ}$. Landslide susceptibility level on a scale from 0 to 5 (after the landslide index method; Zorn and Komac 2008) is around 3, while areas with the highest possible level of landslide susceptibility (scale level 5) can be found in both catchments.

According to the Slovenian Environment Agency, the average temperature was $-1.1^{\circ} \mathrm{C}$ in January and $20.1^{\circ} \mathrm{C}$ in July in the period from 1981 to 2010 . The area gets about $980 \mathrm{~mm}$ of precipitation on average, with just under $4200 \mathrm{MJ} / \mathrm{m}^{2}$ of insolation. Annual snow cover spans from 42 to 56 days. The average evapotranspiration is just over $630 \mathrm{~mm}$ and, on average, about $350 \mathrm{~mm}$ of water drains from the area. The net groundwater recharge is about $80 \mathrm{~mm}$ on average but it can vary significantly. The variation coefficient of groundwater recharge is $82 \%$ in the Jarenina Creek catchment and 52\% in the Vukovje Creek catchment. Parts of the pilot area experience soil water shortage (over 80\%) up to 20 days or more. Both catchments have watercourses of the first, second, and third order (Figure 6).

Land use is similar in both catchments. About one-third of the area is covered by meadows, followed by forests and arable fields. The percentage of the forested area is lower in the Jarenina Creek catchment than in the Vukovje Creek catchment, while the percentage of arable land is somewhat higher. The fourth category is built-up areas, while other areas include vineyards, permanent crops, and overgrown areas. There are only a few tenths of a percent of water surfaces and wetlands.

The catchments considered have identical natural geographical features. However, it was confirmed that the Jarenina Creek catchment has been more reshaped by human activity. This is confirmed by the higher share of built-up areas and agricultural land use. However, today there is more forest than in the first half of the $19^{\text {th }}$ century and fewer fields and vineyards (Deriaz et al. 2019; Gabrovec and Kumer 2019).

\section{Methods}

We selected seven small retention ponds in the Pesnica River catchment to conduct detailed analyses using geoinformation tools and structured interviews with the water pond owners (Figure 2). A structured interview (Šmid Hribar and Ledinek Lozej 2013; Pipan and Kokalj 2017) is a technique for the systematic gathering of verbal information. It was used to record opinions and determine the interviewee's position (Nared 2007) on the selected examples of anthropogenic bodies of water in order to analyze their common features. We studied these examples to determine the main characteristics of the management system of small retention ponds, their versatility, and challenges. The interviews were structured with the following sequence of questions:

- Who is the landowner?

- Who manages the water body?

- What year was the pond established?

- What was it primarily used for?

- What is its current purpose?

- What is the depth of the water?

- What is the speed of sediment accumulation and how often does it have to be removed?

- Do the pond banks have to be maintained?

- Has the pond ever been (over)flooded?

The results enabled us to evaluate the sustainability of the ponds from the management perspective (i.e. maintenance efforts, the quantity of sediment input, primary purpose, frequency of flooding).

Based on field observations and the information gained from the interviews, a pilot study was designed to map and classify all the retention ponds in the catchments of the two Pesnica River tributaries: the Jarenina and Vukovje Creeks which both contribute to the Pernica 1 retention pond (Figures 1 and 2).

All the retention ponds in the pilot area were mapped in the geographic information system and a pond inventory was created. The collected data included:

- Catchment name;

- Location (coordinates); 
- ID number and name of the pond;

- Pond surface area $\left(\mathrm{m}^{2}\right)$;

- Description of the hinterland - inflow;

- Description of the area of the water reservoir - outflow.

We calculated the percentage of small retention ponds that are constructed on the main watercourse and influence water discharge and sediment yield and a percentage of ponds that work with a bypass channel.

\section{Results and discussion}

\subsection{Interviews with the pond owners}

The structured interviews with the owners of the small retention ponds served as an insight into the common challenges regarding their management observed in previous studies: from legislation issues (Širca 2010 ) to costs related to maintenance (Verstraeten and Poesen 1999; 2000; 2001) and the motivation to maintain or abandon the ponds (Mioduszewski 2012). The results show that in the Pesnica River catchment the ponds are usually privately owned and the owners manage them by themselves. Although they are responsible for the operative as well as financial aspects of management they mostly lack experience with any possible authorities responsible for water-related topics. Understandably, since also the review of legislation about small retention ponds in Slovenia showed there are no specific and clear laws and rules (they apply only for large retention ponds). In most cases, the uncertainties and confusion of the legislation do not create problems for individual landowners to establish private ponds. In only one case, the interviewee reported an issue with acquiring a permit to remove sediments from his retention pond in the Vukovje Creek catchment. Consequently, the pond was abandoned and is currently empty.

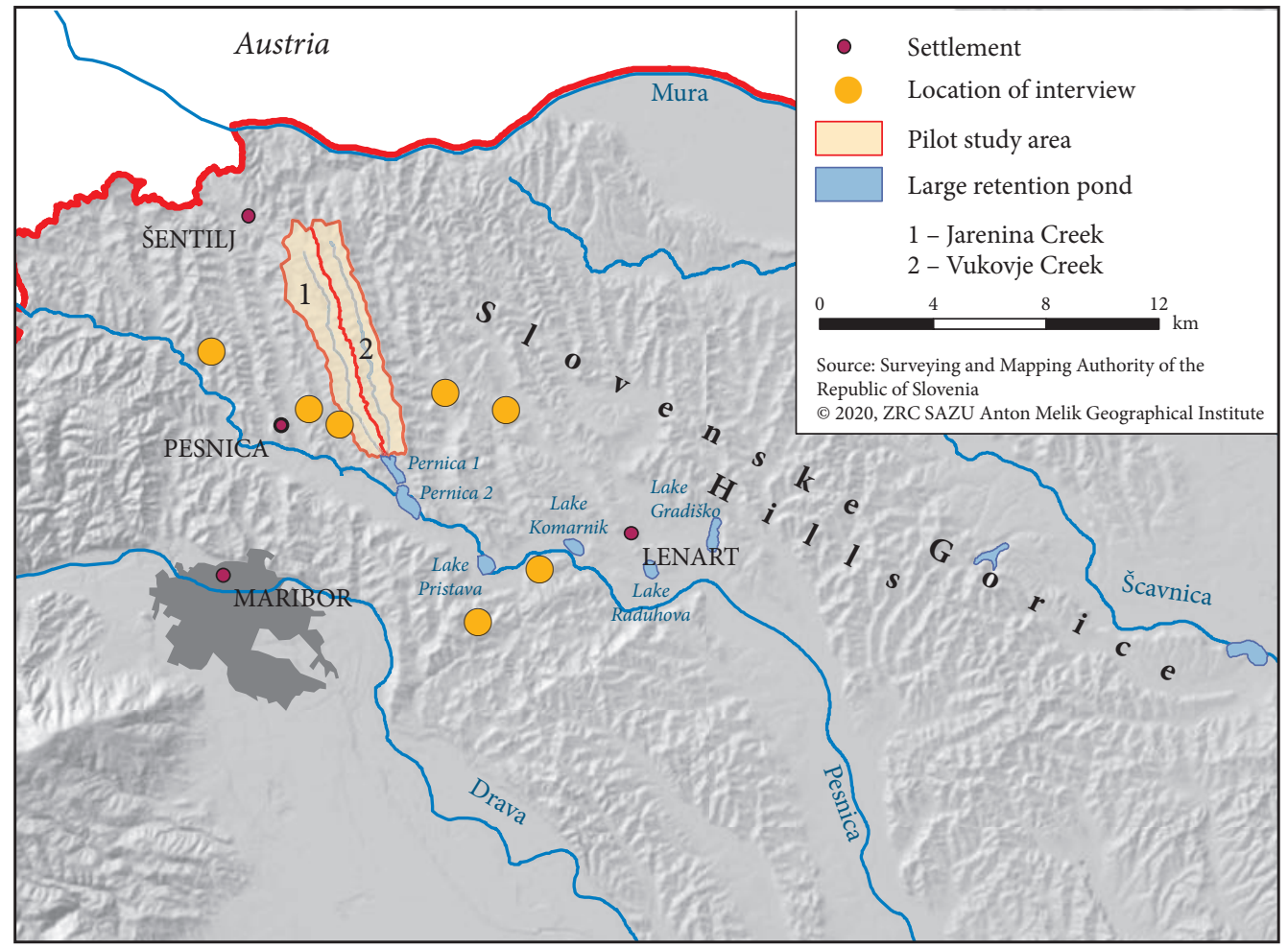

Figure 2: Location of small retention ponds included in the interviews with the pond owners and the pilot study area. 
Based on their primary function when they were created and also their current function the ponds can be divided into two main groups: fishing ponds (commercial and non-commercial) and irrigation ponds. Some retention ponds have existed for hundreds of years. They were made for aesthetic reasons and for fish farming near castles (e.g. Hrastovec Castle; Figure 3), countryside mansions (e.g. former Rittersberg in Spodnji Jakobski Dol), or monasteries (e.g. the Benedictine Monastery at Jareninski Dvor; Figure 4). They can be distinguished from most other ponds by their larger size, which is a consequence also of the favorable environmental conditions: they were created in natural stream valleys, at large natural springs, and in lower basins with permanently high groundwater levels. Through time and the changes in ownership, their function was adapted to the owners' needs. However, the ornamental and fishing ponds have mostly preserved their original function to this day.

Decades ago, fish cultivation was an additional source of income for farmers in the Slovenske Gorice Hills. Nowadays, the financial impact is minimal, leading many of the owners to abandon the fishing ponds. According to the interviewees, the lower income from fish sales in the past decade is most likely a consequence of the dominating low-priced products by major manufacturers on the market. Their observations are in line with the findings at the European Union level where the economic performance of fish farming was linked to the heavy global competition but also to market requirements for the constant supply and quality with guaranteed environmentally-friendly production chains (Review of the EU ... 2009). Competing with such requirements is impossible for individual, non-aligned farmers. Further factors negatively influencing aquaculture development are water user conflicts and increasingly complex regulations (Review of the EU ... 2009). Consequently, commercial fish farming will become economically beneficial only if it is integrated into national strategic development plans, providing the farmers with economic stimulations and legal advice, and connecting them into local production chains (Adámek, Mosser and Hauber 2019).

The other group of retention ponds is intended for irrigation to maximize or stabilize crop yields. They were constructed in the 1990s when state subventions were made available. The irrigation water is used in orchards, vineyards and private gardens. The interviews revealed that the pond maintenance costs for the owners are comparable with the gains of irrigation. Therefore, the owners are looking for additional possibilities to use the existing ponds, otherwise, the ponds will be abandoned. Consequently, the trend of retention pond use is shifting towards an increasingly multi-functional role: irrigation, watering livestock, tourism with non-commercial sports fishing, and the aesthetic function is gaining in importance. Also, other research has shown that public awareness of the benefits of multi-functional ponds encourages local people to properly maintain them (Oda et al. 2019). Due to increased climate variability and

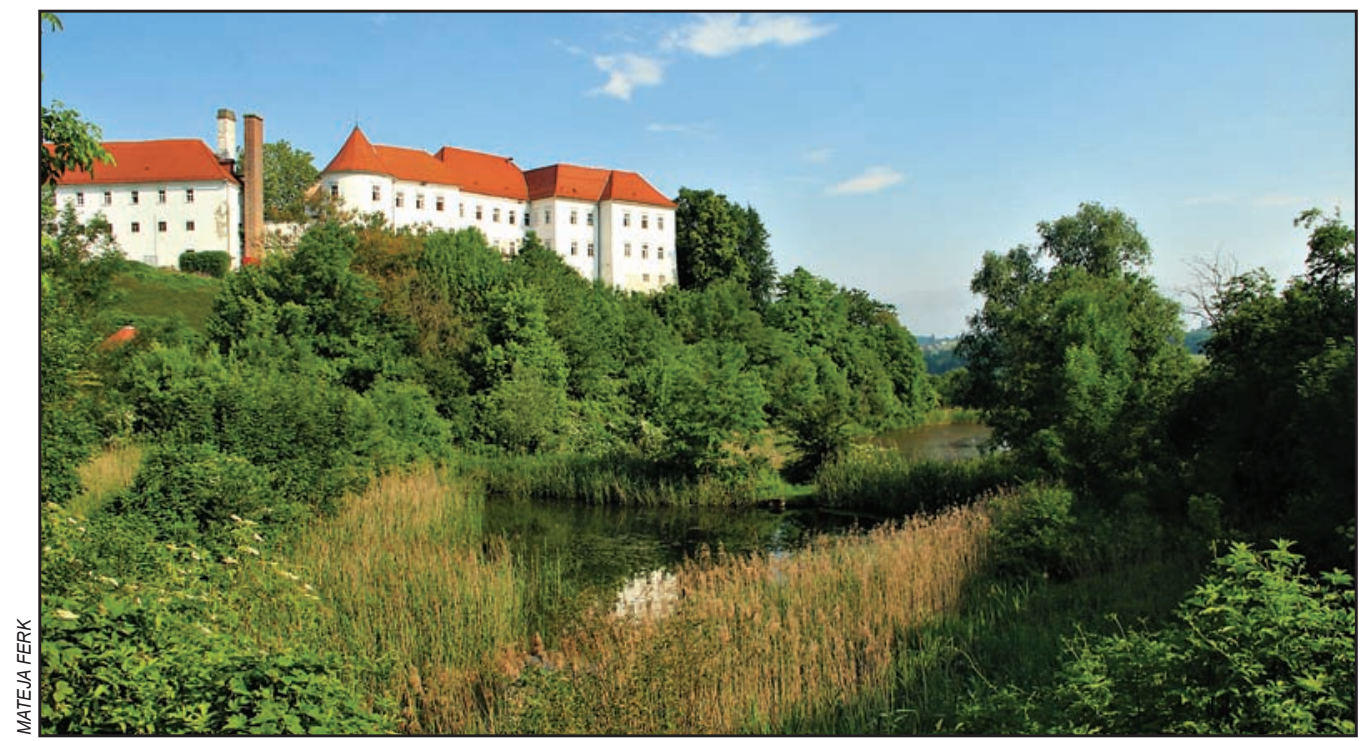

Figure 3: The tradition of fishing in the castle ponds at Hrastovec Castle has been maintained for several centuries. 
change in precipitation patterns (see chapter 2) the need for irrigation ponds will most likely increase in the future. Furthermore, small on-farm ponds are a more sustainable water source, compared to large scale groundwater extraction for irrigation (Sanfo et al. 2017; Vico, Tamburino and Rigby 2020).

Usually, retention ponds are constructed in areas of local springs and streams. Consequently, constructing them requires simply digging out or deepening a small basin in the valley floor, with minimal construction of barriers or dams. Simple dams are constructed by piling up clay sediment and fortified in places with wooden stakes. Some interviewed pond owners stated the ponds were constructed many decades ago by previous landowners. In such cases, the knowledge about motivation and reasons for constructing the ponds at a specific location in a specific way is lost.

The bedrock of the Slovenske Gorice Hills is prone to quick weathering and erosion. Furthermore, despite the fact that these shallow retention ponds are no more than $5 \mathrm{~m}$ deep, they do not need to be frequently cleaned as the accumulation of sediment is still slow. The owners remove the sediment from the ponds only once in every 10 to 30 years. There are several reasons for that, demonstrating the deep understanding and knowledge of local people about their environment:

- The retention ponds are usually located in areas with low inclination slopes, where the torrential character of the watercourses is decreased.

- Low sediment accumulation occurs also because the retention ponds were generally created above the main watercourses and are not subject to flooding.

- Many ponds are built on springs or small tributaries transporting low amounts of bedload.

- When the ponds are built next to the streams, to minimize pond sedimentation, the main watercourse is commonly diverted to bypass the pond (Figure 5). The inundation of ponds is controlled by water channeled from the main watercourse which transports significantly less bedload material. In this way, the owners avoided possible damage during floods and high sediment flow along the main streams.

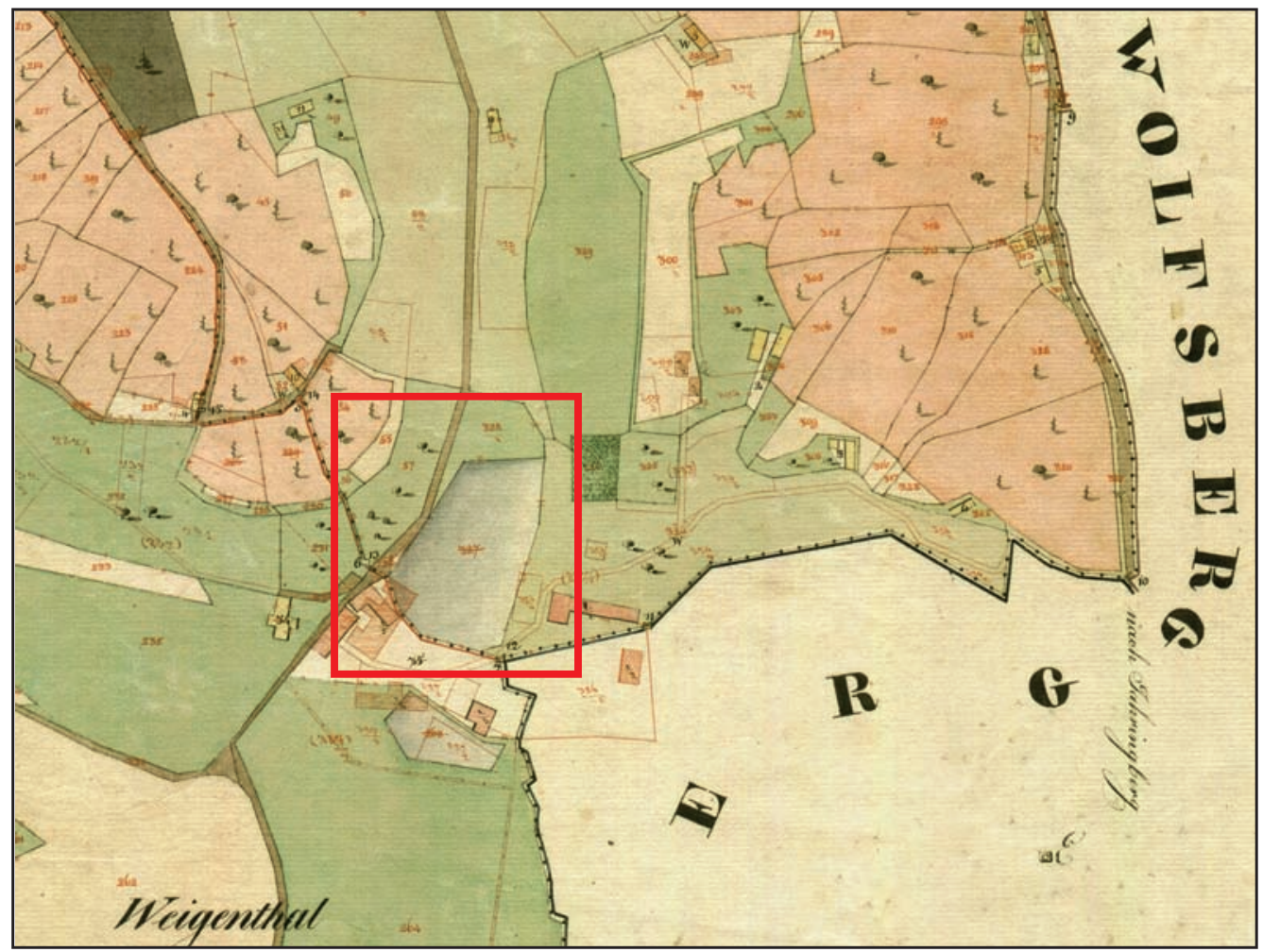

Figure 4: Fishing pond (marked with red rectangle) at the Benedictine Monastery at Jareninski Dvor as shown on the Franciscean Cadastre from the early $19^{\text {th }}$ century (Franciscejski kataster 1824). 
These adaptation methods helping the owners to more efficiently manage and maintain the ponds, influence also the effect of the ponds as possible natural ecological measures for preventing floods. For this reason, we analyzed the percentage of retention ponds in the pilot areas that are located directly on the stream network and the number of ponds that are physically separated from the watercourses and only filled with groundwater or precipitation (chapter 4.2).

Since the issue of pond sedimentation was frequently already limited by creating specific resilient pond types, some interviewed pond owners reported the removal of aquatic weeds from the retention ponds as the most time and cost consuming management issue. Overgrowth by vegetation causes problems because it alters the ecological conditions in the ponds very quickly by inducing eutrophication, overgrowth of the surface with algae, leading to low visibility and low oxygen level (Vanacker et al. 2016). Such changes in water properties are harmful to fish populations and, consequently, need to be avoided especially in fishing ponds (Vanacker et al. 2016; Adámek, Mosser and Hauber 2019). This is why the vegetation in the retention ponds, and especially on their banks, has to be regularly removed every few years (Figure 5).

\subsection{Pond inventarisation in the catchments of Jarenina and Vukovje Creeks}

A total of 41 artificial structures to retain freshwater (i.e. retention ponds) were detected during field mapping in the Jarenina Creek and Vukovje Creek catchments (Figure 6, Table 2). The identified ponds cover a total area of $15,014.73 \mathrm{~m}^{2}$ and the average pond size is $366.21 \mathrm{~m}^{2}$. Despite the comparable size of both catchments, there are significantly fewer ponds in the Jarenina Creek catchment (15 ponds) than in the Vukovje Creek catchment (26 ponds). However, the largest pond of all (JC1 - 5,125 $\mathrm{m}^{2}$ ) and the average pond size in the Jarenina Creek catchment $\left(642.81 \mathrm{~m}^{2}\right)$ considerably exceed the ponds in the Vukovje Creek catchment (average size is $206.64 \mathrm{~m}^{2}$ ). Also, the total area of ponds in the Jarenina Creek catchment $\left(9,642.10 \mathrm{~m}^{2}\right)$ is larger than in the Vukovje Creek catchment $\left(5,372.63 \mathrm{~m}^{2}\right)$.

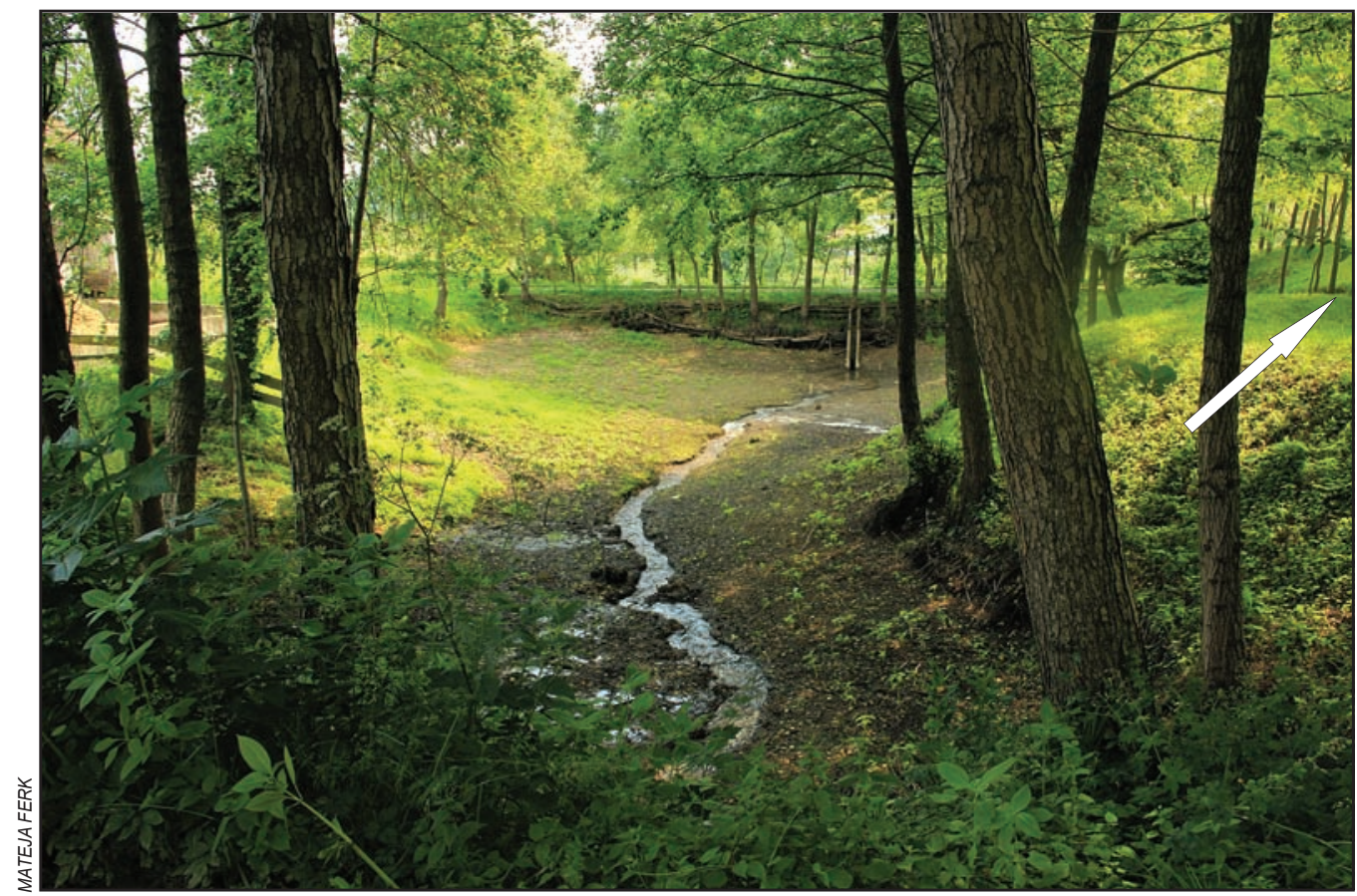

Figure 5: Vegetation is removed from the banks of the retention ponds every few years. White arrow is indicating the location of the diversion channel which diverts the excess water and bedload around the pond. 
Mateja Ferk, Rok Ciglič, Blaž Komac, Dénes Lóczy, Management of small retention ponds and their impact on flood hazard ...

Ponds differ according to the material and method of construction, their source of water, and the way in which water can be drained from the pond (Fish pond ... 2005). Additionally, the possible influence of ponds to decrease flood hazard was evaluated.

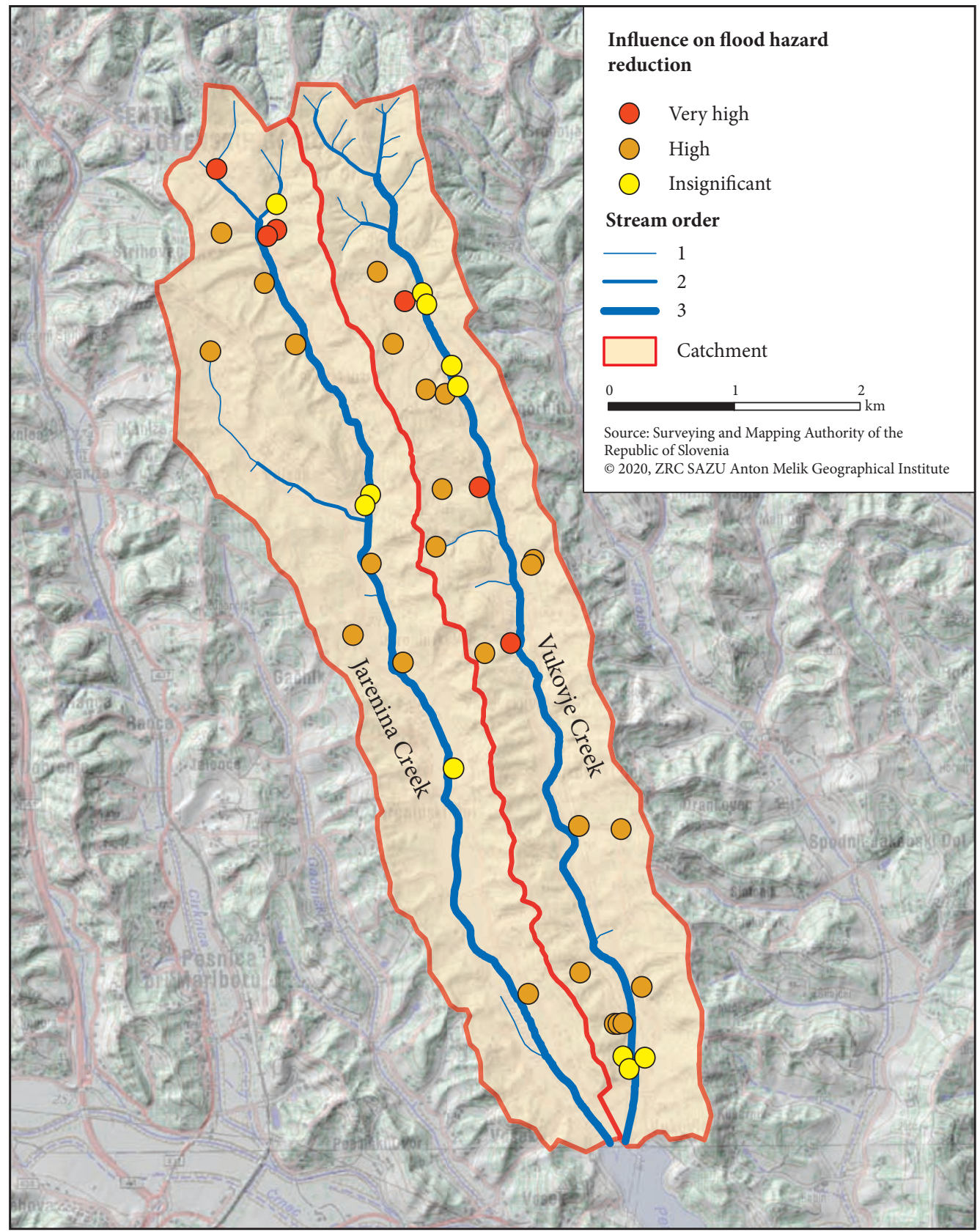

Figure 6: The catchment of Jarenina and Vukovje creeks with the location of small retention ponds classified according to their influence on flood hazard reduction. The figure is showing also the drainage basin network with the order classification (Strahler 1957). The data on the stream network was acquired from the Surveying and Mapping Authority of the Republic of Slovenia. 
All identified ponds in both catchments were built using local natural material (i.e. gravel, sand, clay, soil, and wood) and can be defined as simple earthen ponds. No concrete or metal constructions were used. According to the construction methods, the ponds are either dug-out ponds or cut-and-fill ponds (Table 3 ). The dug-out ponds (also sunken ponds) are constructed in flat areas by excavating bedrock material to form a hole in the ground (Fish pond ... 2005). The excavated material can be used to additionally strengthen or rise pond walls above the surrounding surface. In both catchments 15 ponds (37\%) are dug-out ponds: 5 ponds $(33,3 \%)$ in the Jarenina Creek catchment, and 10 ponds $(38,5 \%)$ in the Vukovje Creek catchment. The cut-and-fill ponds (also barrage ponds) are constructed on slopes by the excavation of the bedrock material and using it to embank the pond on the downslope side (Fish pond ... 2005). In this way, a barrier or dam is built to retain the water. In both catchments, 26 ponds (63\%) are cut-and-fill ponds: 10 ponds $(66,6 \%)$ in the Jarenina Creek catchment, and 16 ponds $(61,5 \%)$ in the Vukovje Creek catchment.

According to the source of water recharge, the ponds can be fed by groundwater or surface water (Fish pond ... 2005). The groundwater can flow to the pond as seepage from the matrix porosity of the bedrock (the level of water will vary with the groundwater-table) or from a spring in or close to the pond (the level of water will vary according to the wet/dry seasons). The surface water can be supplied by rainfall or from surface run-off (e.g. surface stream) both dependent on the wet/dry seasonality. All identified ponds are fed by a combination of water sources (e.g. rainfall and seepage affect all ponds). However, for analytical reasons, the main source of water for each pond was considered in the study (Table 3).

The most common source of water in all identified ponds is groundwater (73\%): $67 \%$ of ponds in the Jarenina Creek catchment and 77\% of ponds in the Vukovje Creek catchment. Approximately two-thirds of the groundwater and $46 \%$ of all the water in both catchments comes from springs. Only three ponds in each catchment are supplied by surface water coming from a stream ( $15 \%$ of all water supply). $12 \%$ of the ponds are mainly supplied by rainfall. Like it was discussed through the interviews with pond owners (see chapter 4.1), also the pond inventarisation confirmed that the pond location (from the aspect of water supply) is well adjusted to the environmental conditions of the Slovenske Gorice Hills. Ponds fed by seepage and spring water transport an insignificant amount of bedload and need less maintenance. From the aspect of sustainability, ponds fed by groundwater (seepage or springs) have a lower amplitude of watertable variability and are less affected by precipitation seasonality. In rural areas, the reliability of the water sources was especially important before the construction of the water distribution system and remained important for livestock and plantation farmers until the present. Moreover, the importance of sustainable small ponds is increasing due to the current climate variability (Sanfo et al. 2017; Vico, Tamburino and Rigby 2020).

Another method (used also by some interviewed pond owners) to prevent flooding and/or filling of ponds with bedload transported by streams is to construct diversion channels to divert excess water and bedload around the pond (Fish pond ... 2005). Out of 6 ponds fed by a surface stream, 4 ponds ( 2 in each

Table 2: Pond inventory of Jarenina (JC) and Vukovje (reek (VC) catchments showing the area of the identified ponds.

\begin{tabular}{|c|c|c|c|c|c|}
\hline ID & area $\left(m^{2}\right)$ & ID & area $\left(m^{2}\right)$ & ID & area $\left(m^{2}\right)$ \\
\hline$J C 1$ & 5125.00 & VC1 & 929.00 & VC16 & 312.00 \\
\hline $\mathrm{JC} 2$ & 801.00 & VC2 & 117.00 & VC17 & 346.00 \\
\hline$J C 3$ & 1103.00 & VC3 & 91.20 & VC18 & 113.00 \\
\hline$J C 4$ & 125.00 & VC4 & 301.00 & VC19 & 204.00 \\
\hline$J C 5$ & 39.00 & VC5 & 64.90 & VC20 & 440.00 \\
\hline$J C 6$ & 31.40 & VC6 & 120.00 & VC21 & 263.00 \\
\hline $\mathrm{JC7}$ & 250.00 & VC7 & 33.00 & VC22 & 138.00 \\
\hline$J C 8$ & 837.00 & VC8 & 6.23 & VC23 & 118.00 \\
\hline$J C 9$ & 271.00 & VC9 & 150.00 & VC24 & 83.80 \\
\hline$J C 10$ & 557.00 & VC10 & 129.00 & VC25 & 141.00 \\
\hline$J C 11$ & 109.00 & VC11 & 267.00 & VC26 & 532.00 \\
\hline $\mathrm{JC} 12$ & 98.40 & VC12 & 54.50 & & \\
\hline $\mathrm{JC13}$ & 88.60 & VC13 & 166.00 & & \\
\hline JC14 & 124.00 & VC14 & 106.00 & & \\
\hline$J C 15$ & 82.70 & VC15 & 147.00 & & \\
\hline
\end{tabular}




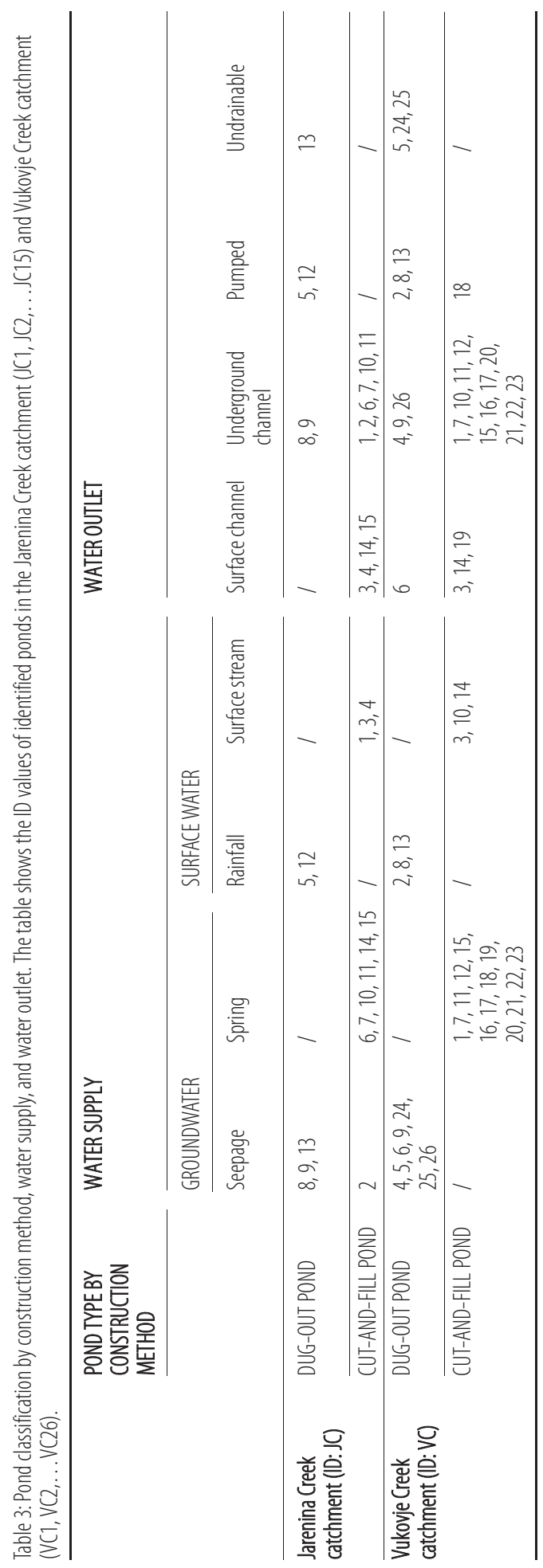


catchment; JC 3 and JC4, and VC 3 and VC14) have a diversion channel. Both ponds in the Vukovje Creek catchment are currently out of operation (surrounded by meadows and partly overgrown by bush). We assume they are several decades old and that the diversion channels played a greater role in the past when they were used as watering holes for livestock. Both ponds in the Jarenina Creek catchment were built in the last two decades and have currently an aesthetic and tourism function. The diversion channels for both ponds are regularly cleaned and maintained. Land use changes (afforestation reflecting the changes in farming economy) altered the function of the majority of ponds. Their maintenance strongly depends on the awareness of pond owners of the possible benefits of multi-functional ponds: irrigation, tourism, and aesthetics.

Considering the supply of water, the surface stream-fed ponds have the most direct impact on water and sediment discharge (Koskiaho 2003; Muendo et al. 2014; Chrétien et al. 2016) by slowing down the run-off and consequently on flood reduction. This effect is lessened by the diversion channels, especially for the bedload which can be transported around the ponds. For water retention in the source area of the catchments also rainfall and spring-fed ponds are important as both types are correlated to precipitation patterns; some excess water is stored in the source area during peak flows decreasing fast drainage towards lower valleys (Koskiaho 2003; Chrétien et al. 2016). Stream, rainfall, and spring-fed ponds are becoming more and more important also for limiting on the impacts of drought at individual and local levels due to increased variability of precipitation patterns (Oda et al. 2019; Vico, Tamburino and Rigby 2020). Ponds fed through seepage do not influence water discharge (i.e. movement of groundwater). Moreover, during floods, these ponds can be completely submerged and are not impacting the extent of floods or sediment transport. On the other hand, because they are excavated below the water-table they represent vulnerable locations for chemical or biological contamination of the groundwater (Lóczy and Dezső 2013).

For sustainable management of ponds also the outlet of water is important which can be drainable or undrainable (Table 3). Drainable outlets can be driven by gravitation (surface streams and underground channels) or the water can be mechanically pumped from the pond. Gravitational outlets are typical for cut-and-fill ponds supplied by springs and surface streams. Mostly they have controlled outlets because they were built by embankment (e.g. barrier or dam) through which a surface or underground channel enables the drainage of excess water. In the Jarenina Creek catchment 12 out of 15 ponds have a controlled surface (4 ponds) or an underground ( 8 ponds) outlet channel. In the Vukovje Creek catchment, 19 out of 26 ponds have a controlled surface ( 4 ponds) or an underground ( 15 ponds) outlet channel. These types of outlets directly influence drainage downstream (e.g. discharge, bedload and suspended sediment, as well as water quality). Therefore, their proper management reduces flood and drought risks. All ponds fed by rainfall ( 5 ponds in both catchments) were excavated on higher ground above the valley floor but have no surface or underground outlet. However, they can be emptied by pumping out water, if needed. Of a special type are ponds fed by seepage, which are deepened below the surrounding surface and cannot be drained (watertable dictates the water level of the pond). As mentioned before, they have the lowest impact on flood reduction but are the most vulnerable point for water pollution, e.g with increased nutrient presence (Ilić and Panjan 2018).

\section{Conclusion}

The paper discusses small water ponds in north-eastern Slovenia on the example of the Slovenske Gorice Hills. The main conclusion is that small retention ponds, unlike large ponds, are not included in the regional, national and international legislation and the management is left to the landowners. Poor and uncoordinated management strategies and low investments contribute to the state of the water ponds and further minimize their possible use in flood protection. We also noted that the long-term landscape changes, especially land use changes, considerably alter the functioning of the small ponds as an important part of the hydrological system. In the last decades, afforestation, related to the changes in the farming economy, lowered the sediment input and shifted the prevailing use of water ponds from commercial fishing, irrigation and watering livestock to other functions, such as tourism, non-commercial fishing, and aesthetics.

More than half of the retention ponds in the catchments of Jarenina and Vukovje creeks are supplied by groundwater (through seepage or springs) which increases the sustainability of ponds because less effort is needed to maintain them (low sedimentation rates, reliable source of water). Only $15 \%$ of the ponds are supplied by surface streams and $12 \%$ by rainfall. The ponds constructed on surface streams largely impact 
the water discharge and sediment transport and reduce the flood hazard. However, their maintenance is more demanding than that of other pond types. To cope with sediment infilling and avoid peak flow damages to ponds, diversion channels were built on two-thirds of such ponds, diverting the majority of bedload and excess water around the ponds. This technique lowers the maintenance efforts and increases pond sustainability, however, it lowers the pond impact on flood hazard reduction.

For water retention in the source area of the catchments both rainfall and spring-fed ponds are important as both types are correlated to precipitation patterns; some excess water is stored in the source area during peak flows decreasing fast drainage towards lower valley sections. Stream, rainfall, and spring-fed ponds are due to increased variability of precipitation patterns becoming more and more important also for limiting drought consequences at an individual and local level. Ponds fed by seepage have an egligible impact on flood risk reduction. Nevertheless, they are vulnerable locations for chemical or biological contamination of the groundwater because they are deepened below the local water-table level.

Since the owners' investments to maintain the retention ponds are relatively high compared to their economic benefits, the owners often choose to abandon retention ponds. Although retention ponds do not prevent floods, their future abandonment would destabilize the hydrological and agriculture system and increase flood risk and drought impact in the area.

ACKNOWLEDGEMENTS: The authors acknowledge the study was performed in the frame of the project Possible ecological control of flood hazard in the hilly regions of Hungary and Slovenia. The project was financially supported by the Slovenian Research Agency (ARRS, N6-0070) and the Hungarian National Research, Development and Innovation Office (NKFIH, SNN 125727 and the programme Excellence in Higher Education, Theme II. 3. »Innovation for sustainable life and environment $)$. The study was performed also in the frame of a research programme Geography of Slovenia (ARRS, P6-0101).

\section{References}

Adámek, Z., Mösser, M., Hauber, M. 2019: Current principles and issues affecting organic carp (Cyprinus carpio) pond farming. Aquaculture 512. DOI: https://doi.org/10.1016/j.aquaculture.2019.734261

Barborič, B., Triglav Čekada, M., Bric, V., Kete, P., Dežman Kete, V. 2017: Nove podatkovne podlage za boljše upravljanje z vodami. Naravne nesreče 4 . Ljubljana.

Belec, B. 1998: Panonski svet. Slovenija, pokrajine in ljudje. Ljubljana.

Chrétien, F., Gagnon, P., Thériault, G., Guillou, M. 2016: Performance analysis of a wet-retention pond in a small agricultural catchment. Journal of Environmental Engineering 142-4. DOI: https://doi.org/ 10.1061/(ASCE)EE.1943-7870.0001081

Ciglič, R., Nagy, G. 2019: Naturalness level of land use in a hilly region in north-eastern Slovenia. Geografski vestnik 91-1. DOI: https://doi.org/10.3986/GV91101

Deriaz, J., Ciglič, R., Ferk, M., Loczy, D. 2019: The influence of different levels of data detail on land use change analyses: a case study of Franciscan Cadastre for a part of the Pannonian Hills, Slovenia. European countryside 11-3. DOI: https://doi.org/10.2478/euco-2019-0019

E-vode, 2019. Medmrežje: http://www.evode.gov.si/index.php?id=1 (4.11.2019).

Fairchild, G. W., Velinsky, D. J. 2009: Effects of small ponds on stream water chemistry. Lake and Reservoir Management 22-4. DOI: https://doi.org/10.1080/07438140609354366

Fish pond construction and management, 2005. A field guide and extension manual.

Franciscejski kataster za Štajersko, k. o. Vajgen [Weigen], list B03. Arhiv Republike Slovenije. Ljubljana, 1824.

Frantar, P. 2008a: Odtočni količniki. Vodna bilanca Slovenije 1971-2000. Ljubljana.

Frantar, P. 2008b: Specifični odtoki 1971-2000. Vodna bilanca Slovenije 1971-2000. Ljubljana.

Frantar, P., Hrvatin, M. 2005: Pretočni režimi v Sloveniji med letoma 1971 in 2000. Geografski vestnik 77-2.

Gabrovec, M., Bičík, I., Komac, B. 2019: Land registers as a source of studying long-term land-use changes. Acta geographica Slovenica 59-2. DOI: https://doi.org/10.3986/AGS.7349

Gabrovec, M., Kumer, P. 2019: Land-use changes in Slovenia from the Franciscean Cadaster until today. Acta geographica Slovenica 59-1. DOI: https://doi.org/10.3986/AGS.4892

Globevnik, L. 2012. Vzdrževanje vodne infrastrukture in vodotokov - pomen, realnost in perspektive. 1. kongres o vodah Slovenije, 22. marec 2012. Ljubljana. 
Hooijer, A., Klijn, F., Pedroli, G. B. M., Van Os, A. G. 2004: Towards sustainable flood risk management in the Rhine and Meuse river basins: synopsis of the findings of IRMA-SPONGE. River Research and Applications 20. DOI: https://doi.org/10.1002/rra.781

Hrvatin, M., Ciglič, R., Lóczy, D., Zorn, M. 2019: Določanje erozije v gričevjih severovzhodne Slovenije z Gavrilovićevo enačbo. Geografski vestnik 91-2. DOI: https://doi.org/10.3986/GV91206

Hrvatin, M., Zorn, M. 2017: Trendi pretokov rek v slovenskih Alpah med letoma 1961 in 2010. Geografski vestnik 89-2. DOI: https://doi.org/10.3986/GV89201

Ilić, D., Panjan, J. 2018: Nitrogen and phosphorus pollution in Goričko Nature Park. Acta geographica Slovenica 58-1. DOI: https://doi.org/10.3986/AGS.727

Infrastructure for SPatial InfoRmation in Europe - INSPIRE. Brussels, 2017. Internet: https://inspire.ec.europa.eu/ about-inspire/563 (21. 10.1019).

Juvan, S., Hojnik, T., Kaligarič, S., Trop, M. 1997: Presoja vplivov načrtovanega poteka AC po pesniški dolini na vodni režim in vodno okolje. Mišičev vodarski dan, zbornik referatov. Maribor.

Kert, B. 1998: Slovenske gorice. Slovenija, pokrajine in ljudje. Ljubljana.

Kijowska-Strugała, M., Bucała-Hrabia, A. 2019: Flood types in a mountain catchment: The Ochotnica River, Poland. Acta geographica Slovenica 59-1. DOI: https://doi.org/10.3986/AGS.2250

Kladnik, D., Geršič, M., Pipan, P., Volk Bahun, M. 2019: Land-use changes in Slovenian terraced landscapes. Acta geographica Slovenica 59-2. DOI: https://doi.org/10.3986/AGS.6988

Kobold, M. (ur.) 2012: Hidrološki letopis Slovenije 2009. Ljubljana.

Kolbezen, M. 1998: Kopenske vode. Geografski atlas Slovenije. Ljubljana.

Komac, B. 2015: Modeliranje obpotresnih pobočnih procesov v Sloveniji. Geografski vestnik 87-1. DOI: https://doi.org/10.3986/GV87107

Komac, B., Zorn, M. 2011: Vloga zavarovanih območij pri blažitvi naravnih nesreč. Razvoj zavarovanih območij v Sloveniji. Regionalni razvoj 3. Ljubljana.

Komac, B., Zorn, M. 2016: Naravne in umetne pregrade ter z njimi povezani hidro-geomorfni procesi. Geografski vestnik 88-2. DOI: https://doi.org/10.3986/GV88204

Koskiaho, J. 2003: Flow velocity retardation and sediment retention in two constructed wetland-ponds. Ecological Engineering 19-5. DOI: https://doi.org/10.1016/S0925-8574(02)00119-2

Kovačič, G. 2016: Discharge trends of the Adriatic Sea basin rivers in Slovenia, excluding the Soča river basin. Geografski vestnik 88-2. DOI: https://doi.org/10.3986/GV88201

Kozjek, K., Dolinar, M., Skok, G. 2017: Objective climate classification of Slovenia. International journal of climatology 37-S1. DOI: https://doi.org/10.1002/joc.5042

Kračun, M. 2010: Analiza zamuljevanja akumulacije Pernica z vidika njenega namena. Varnost pregrad v Sloveniji. 12. posvetovanje Slovenskega nacionalnega komiteja za velike pregrade (SLOCOLD). Krško.

Leitinger, V. 2012: Hidrografske značilnosti porečja reke Pesnice s poudarkom na vodnogospodarskih ureditvah. Diplomsko delo, Fakulteta za humanistične študije Univerze na Primorskem. Koper.

Lenart, S., Rajar, R., Širca, A. 2017: Prispevek projekta VODPREG 2 k oceni porušitev vodnih pregrad. Trajnostni razvoj mest in naravne nesreče. Naravne nesreče 4. Ljubljana.

Lóczy, D., Dezső, J. 2013: Groundwater flooding hazard in river valleys of hill regions: example of the Kapos River, Southwest-Hungary. Hungarian Geographical Bulletin 62-2.

Lóczy, D., Kis, E., Schweitzer, F. 2009: Local flood hazards assessed from channel morphometry along the Tisza River in Hungary. Geomorphology 113. DOI: https://doi.org/10.1016/j.geomorph.2009.03.013

Manifesto: Dams \& Reservoirs 2015. Issue 1. European ICOLD Club. October 2015.

Mioduszewski, W. 2012: Small water reservoirs - their function and construction. Journal of Water and Land Development 17-VII-XII.

Muendo, P. N., Verdegem, M. C. J., Stoorvogel, J. J., Milstein, A., Gamal, E., Minh Duc, P., Verreth, J. A. J. 2014: Sediment accumulation in fish ponds; Its potential for agricultural use. International Journal of Fisheries and Aquatic Studies 1-5.

Načrt upravljanja voda na vodnem območju Donave za obdobje 2016-2021, 2016. Internet: https://www.gov.si/ assets/ministrstva/MOP/Dokumenti/Voda/NUV/63dbe4066b/NUV_VOD.pdf (5. 10.2019).

Načrt upravljanja voda na vodnem območju Jadranskega morja za obdobje 2016-2021, 2016. Internet: https://www.gov.si/assets/ministrstva/MOP/Dokumenti/Voda/NUV/4195091b63/NUV_VOJM.pdf (28.2.2020).

Nared, J. 2007: Prostorski vplivi slovenske regionalne politike. Geografija Slovenije 16. Ljubljana. 
Natek, K. 1992: Franciscejski kataster in geografski informacijski sistem. Traditiones 21.

Oda, T., Moriwaki, K., Tanigaki, K., Nomura, Y., Sumi, T. 2019: Irrigation ponds in the past, present, and future: A case study of the Higashi Harima Region, Hyogo Prefecture, Japan. Journal of Hydro-environment Research 26. DOI: https://doi.org/10.1016/j.jher.2018.11.004

Papež, J. 2010: Obseg in pomen rednega urejanja voda. Varnost pregrad v Sloveniji. 12. posvetovanje Slovenskega nacionalnega komiteja za velike pregrade (SLOCOLD). Krško.

Perko, D. 1998: The regionalization of Slovenia. Acta geographica 38.

Pintar, J., Mikoš, M., Verbovšek, V. 1986: Elementi okolju prilagojenega urejanja vodotokov: alternativa utesnjevanju živih naravnih procesov v toge objekte. Drugi kongres o vodama Jugoslavije. Beograd.

Pipan, P. Kokalj, Ž. 2017: Transformation of the Jeruzalem Hills cultural landscape with modern vineyard terraces. Acta geographica Slovenica 57-2. DOI: https://doi.org/10.3986/AGS.4629

Pravilnik o določitvi vodne infrastrukture. Uradni list Republike Slovenije 46/2005. Ljubljana.

Pravilnik o opazovanju seizmičnosti na območju velike pregrade. Uradni list Republike Slovenije 92/1999, 44/2003 in 58/2016. Ljubljana.

Pravilnik o tehničnem opazovanju visokih jezov. Uradni list Socialistične federativne republike Jugoslavije 7/1966. Beograd.

Pravilnik o vodnem katastru. Uradni list Republike Slovenije 30/2017. Ljubljana.

Review of the EU aquaculture sector and results of costs and earnings survey 2009. Definition of data collection needs for aquaculture, Final report.

Richert, E., Bianchin, S., Heilmeier, H., Merta, M., Seidler, C. 2011: A method for linking results from an evaluation of land use scenarios from the viewpoint of flood prevention and nature conservation. Landscape and Urban Planning 103. DOI: https://doi.org/10.1016/j.landurbplan.2011.07.001

Sanfo, S., Barbier, B., Dabiré, I. W. P., Vlek, P. L. G., Fonta, W. M., Ibrahim, B., Barry, B. 2017: Rainfall variability adaptation strategies: An ex-ante assessment of supplemental irrigation from farm ponds in southern Burkina Faso. Agricultural Systems 152. DOI: https://doi.org/10.1016/j.agsy.2016.12.011

Seznam obstoječe vodne infrastrukture. Uradni list Republike Slovenije 63/2006, 96/2006. Medmrežje: http://www.pisrs.si/Pis.web/pregledPredpisa?id=DRUG2548

Sodnik, J., Kogovšek, B., Mikoš, M. 2014: Vodna infrastruktura v Sloveniji: kako do ocene realnega stanja? Naravne nesreče 3. Ljubljana.

Steinman, F., Banovec, P. 2008: Hidrotehnika, Vodne zgradbe I. Univerza v Ljubljana, Fakulteta za gradbeništvo in geodezijo. Ljubljana. Medmrežje: http://fgg-web.fgg.uni-lj.si/kmte/documents/academic/ skripta/Hidrotehnika_sept.2008.pdf

Strahler, A. N. 1957: Quantitative analysis of watershed geomorphology. Transactions of the American Geophysical Union 38-6. DOI: https://doi.org/10.1029/tr038i006p00913

Širca, A. 2010: Slovenske velike pregrade: stanje, perspektive in ovire. Varnost pregrad v Sloveniji. 12. posvetovanje Slovenskega nacionalnega komiteja za velike pregrade (SLOCOLD). Krško.

Širca, A., Ravnikar Turk, M., Zadnik, B. 2010: Vloga strokovnih združenj pri izboljševanju varnosti pregrad. Varnost pregrad v Sloveniji. 12. posvetovanje Slovenskega nacionalnega komiteja za velike pregrade (SLOCOLD). Krško.

Šmid Hribar, M., Ledinek Lozej, Š. 2013: The role of identifying and managing cultural values in rural development. Acta geographica Slovenica 53-4. DOI: https://doi.org/10.3986/AGS53402

Trobec, T. 2016: Prostorsko-časovna razporeditev hudourniških poplav v Sloveniji. Dela 46. DOI: https://doi.org/ 10.4312/dela.46.5-39

Uputstvo o izradi dokumentacije za određivanje posledica usled iznenadnog rušenja ili prelivanja visokih brana. Savezni komitet za poljoprivredu, 1975. Beograd.

Uredba o načrtih upravljanja voda na vodnih območjih Donave in Jadranskega morja. Uradni list Republike Slovenije 67/2016. Ljubljana.

Vanacker, M., Wezel, A., Arthaud, F., Guérin, M., Robin, J. 2016: Determination of tipping points for aquatic plants and water quality parameters in fish pond systems: A multi-year approach. Ecological Indicators 64 . DOI: https://doi.org/10.1016/j.ecolind.2015.12.033

Verstraeten, G., Poesen, J. 1999: The nature of small-scale flooding, muddy floods and retention pond sedimentation in central Belgium. Geomorphology 29.

Verstraeten, G., Poesen, J. 2000: Estimating trap efficiency of small reservoirs and ponds: methods and implications for the assessment of sediment yield. Progress in Physical Geography 24-2. 
Verstraeten, G., Poesen, J. 2001: Variability of dry sediment bulk density between and within retention ponds and its impact on the calculation of sediment yields. Earth Surface Processes and Landforms 26-4. DOI: https://doi.org/10.1002/esp.186

Vico, G., Tamburino, L., Rigby, J. R. 2020: Designing on-farm irrigation ponds for high and stable yield for different climates and risk-coping attitudes. Journal of Hydrology 584. DOI: https://doi.org/10.1016/ j.jhydrol.2020.124634

World declaration on water storage for sustainable development. 24th Congress of the International Commission on Large Dams, 5.6.2012. Internet: https://www.icold-cigb.org/userfiles/files/World\% 20declaration/World\%20Declaration-ENG.pdf (15.2.2020).

World register of dams. International Commission on Large Dams, September 2019. Internet: https://www.icoldcigb.org/ (24.2.2020).

Wutich, A., White, A. C., White, D. D., Larson, K. L., Brewis, A., Roberts, C. 2014: Hard paths, soft paths or no paths? Cross-cultural perceptions of water solutions. Hydrology and Earth System Sciences 18. DOI: https://doi.org/10.5194/hess-18-109-2014

Zakon o vodah. Uradni list Republike Slovenije 67/2002, 2/2004, 41/2004, 57/2008, 57/2012, 100/2013, 40/2014 in 56/2015. Ljubljana.

Zemeljske in betonske vodne pregrade strateškega pomena v Republiki Sloveniji, VODPREG2, 2016. Razvojno raziskovalni projekt, Končno poročilo. Zavod za gradbeništvo, IBE d. d., Fakulteta za gradbeništvo in geodezijo, Ljubljana, Hidrotehnik d. d. Ljubljana.

Zorn, M. 2007: Jožefinski vojaški zemljevid kot geografski vir. Geografski vestnik 79-2.

Zorn, M., Komac, B. 2008: Zemeljski plazovi v Sloveniji. Georitem 8. Ljubljana.

Žiberna, I. 2017: Trendi vodne bilance v severovzhodni Sloveniji v obdobju 1961-2016. Geografija Podravja. Maribor. 